\title{
Putin Stirs Up UN General Assembly
}

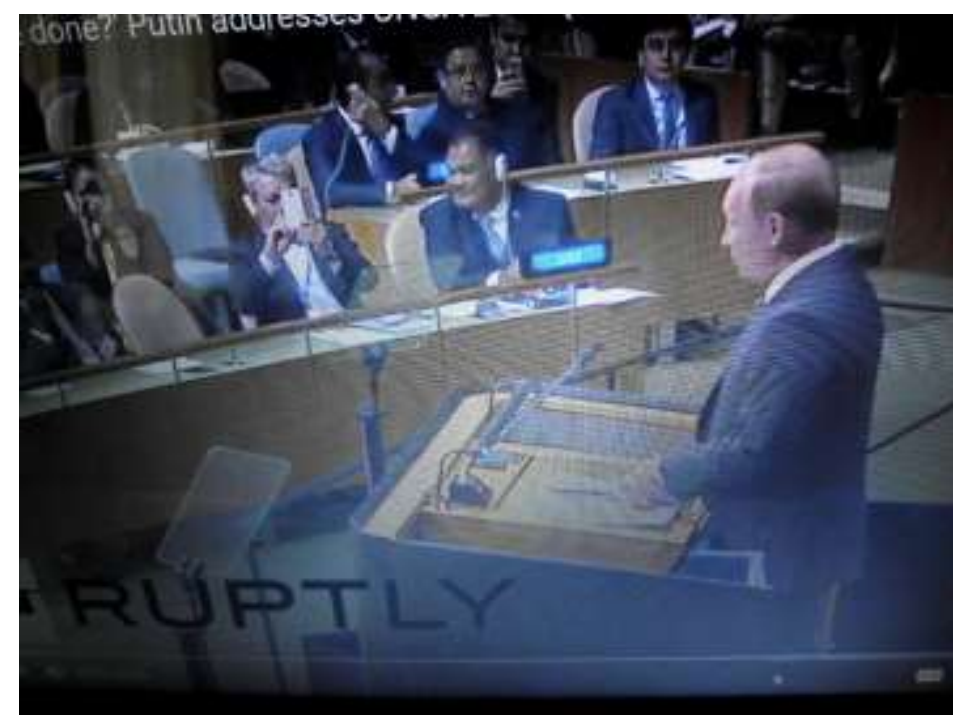

Photograph Credit: Teena Brown Pulu

Three Tuvalu delegates had front-row seats for Vladimir Putin's speech to the United Nations General Assembly at the first day of the general debate on Monday September 28th, 2015. Smartphones in hand taking snapshots of the Russian President settling in at the podium, the wowed expressions on their faces made Putin appear like a UN superstar on centre stage.

Putin hadn't attended the assembly in a decade. He had a strong message to belt across the green hall to commemorate the United Nations seventieth year of establishment. 
He traced Russia's roots in the United Nations to its birthplace at the Yalta Conference from February 4th to the 11th, 1945. Back then, it was Premier Joseph Stalin for the Soviet Union representing Eastern Europe's interests in shaping up the post-war peace and new world order after the defeat of Nazi Germany. The other two leaders at Yalta were Prime Minister Winston Churchill for the United Kingdom, and President Franklin D. Roosevelt for the United States.

The seventieth anniversary of the United Nations is a good occasion to both take stock of history, and talk about our common future. In 1945, the countries that defeated Nazism joined their efforts to make solid foundations for the post-world war order. Let me remind you that the key decisions on the principles guiding the cooperation as well as the establishment of the United Nations were made in our country, in Yalta at the meeting of the anti-Hitler coalition leaders.

In 2015, Putin wanted to re-establish an alliance "of all the forces that confront the Islamic State and other terrorist organisations," including the United States. He was determined to stop the war in Syria, and by doing so, strengthen the state so that citizens weren't forced to flee to Europe.

First of all, we propose discussing whether it is possible to agree on a resolution aimed at coordinating the actions of all the forces that confront the Islamic State and other terrorist organisations. Once again, this coordination should be based on the principles of the UN charter. We hope that the international community will be able to develop a comprehensive strategy of political stabilisation, as well as social and economic recovery of the Middle East. Then, there would be no need for new refugee camps. Today, the 
flow of people who were forced to leave their homeland has literally engulfed neighbouring countries, and then Europe itself. There are hundreds of thousands of them now, and there might be millions before long. In fact, it is a new, great, and tragic migration of peoples, and it is a harsh lesson for all of us, including Europe.

Anissa Naouai for Russia Today characterised an aspect of the General Assembly Hall. "There's another side to this giant chamber - the audience - who witness, admire, or protest policy, and if you don't like something or someone, you get up and leave."

Ukraine President, Petro Poroshenko, played right into the stereotype. When Putin got up to speak, he loudly left the room with his posse. The Ukrainian President refused to listen to his Russian counterpart arguing for an alliance of countries to stop the war in Syria.

Asked by Russian television what he thought of Poroshenko's staged exit with the Ukrainian delegation, Putin was blunt.

I did not know that the Ukrainian President was not present when I gave my speech. I don't really care. I don't need everybody to be present, especially if somebody's not interested and doesn't want to listen.

Poroshenko had an axe to grind over losing Crimea to Russia in March of 2014. On the second day of the general debate, he zealously took to the podium to name, blame, and shame Russia as the ogre of international relations.

"My country has become the object of their external aggression," roared the Ukrainian President. "The aggressor is the Russian Federation." Applause rang out from the Ukraine delegation seated in the audience. The Russian Federation table was empty. As Naouai remarked, "if you don't like 
someone, you get up and leave," or, you just don't show up to begin with.

Poroshenko wound himself up for the grand finale fortifying his twenty-eight minute speech. He wanted a United Nations intervention in Crimea to restore the territory to Ukraine.

I believe that the problem of blatant violation of human rights in Crimea deserves particular consideration within [the] UN General Assembly. And I hope the decision to address this issue will be taken during the current session.

Poroshenko was in his own little world. Slavoj Zizek noted, he muddled historical fact. It was the Russian Bolsheviks "who created Ukraine as a full nation." Perched on Russia's border, the national security threat Ukraine posed was Kiev's endless instability, which had sent one million Ukrainian refugees across the state-line from the Donbass region into Russia.

Ukrainians should remember it was the Bolsheviks in the first ten years of [the] Soviet Union who created Ukraine as a full nation. What I fear is that Ukraine will become another part of the world where there is some kind of half-peace without unified state power structure. What I'm afraid [of is] this kind of neither war nor peace, a little bit of shooting then a ceasefire, will basically go on endlessly and it will become a permanent feature.

But it was China's President X Jinping who stole the show for developing countries with Chinese soft loans for infrastructure development, including Pacific Islands' states. Would the "China UN peace and development fund" valued at "1 billion US dollars" mean debt forgiven for unpaid loans? 
China will continue to participate in building world peace. We are committed to peaceful development. No matter how the international landscape may evolve, or, how strong China may become, China will never pursue hegemony, expansion, or sphere of influence. China's vote in the United Nations will always belong to the developing countries. I wish to take this opportunity to announce China's decision to establish a ten-year 1 billon US dollars, China UN peace and development fund to support the UN's work.

The original triangle of the United Kingdom, United States, and Soviet Union that launched the United Nations in 1945, had transformed seventy years on to resemble America, Russia, and China. How well did President Obama and Washington bureaucrats comprehend the centre of gravity for twenty-first century international relations had changed from last century? 